Joseph C. Miller Memorial Lecture Series

eds. Abdelkader Al Ghouz, Jeannine Bischoff, Sarah Dusend

\title{
Maria Ågren
}

\section{At the Intersection of Labour History and Digital Humanities: What Vaguely Described Work Can Tell Us about Labour Relations in the Past}




\section{At the Intersection of Labour History and Digital Humanities: What Vaguely Described Work Can Tell Us about Labour Relations in the Past}




\section{Joseph C. Miller Memorial Lecture Series}

eds. Abdelkader Al Ghouz, Jeannine Bischoff, Sarah Dusend

\section{Volume 2}

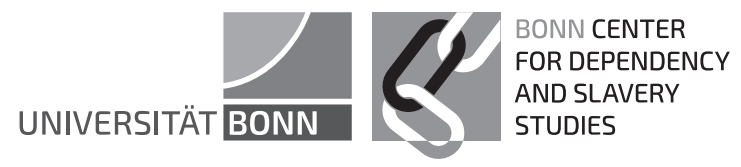


Maria Ågren

\section{At the Intersection of Labour History and Digital Humanities: What Vaguely Described Work Can Tell Us about Labour Relations in the Past}

ebv

BERLIN

EBVERLAG 
Bibliographic information published by the Deutsche Nationalbibliothek

The Deutsche Nationalbibliothek lists this publication in the Deutsche

Nationalbibliografie; detailed bibliographic data are available in the Internet at http://dnb.d-nb.de

Gefördert durch die Deutsche Forschungsgemeinschaft (DFG) im Rahmen der Exzellenzstrategie des Bundes und der Länder Exzellenzcluster Bonn Center for Dependency and Slavery Studies (BCDSS) EXC 2036/1-2020, Projektnummer: 390683433
All rights reserved. No part of this book may be reproduced in any form or by any electronic or mechanical means, including information storage and retrieval systems, without written permission from the publisher or author, except in the case of a reviewer, who may quote brief passages embodied in critical articles or in a review.

Funded by the Deutsche

Forschungsgemeinschaft (DFG, German

Research Foundation) under Germany's

Excellence Strategy - Cluster of Excellence

Bonn Center for Dependency and Slavery

Studies (BCDSS) EXC 2036/1-2020, Project No.: 390683433

\section{(C) $(1) \Theta$}

This work is licensed under the Creative Commons Attribution-NonCommercial-NoDerivatives 4.0 (BY-NC-ND) which means that the text may be used for non-commercial purposes, provided credit is given to the author. For details go to http://creativecommons.org/licenses/by-nc-nd/4.0/

To create an adaptation, translation, or derivative of the original work and for commercial use, further permission is required and can be obtained by contacting post@ebverlag.de

Creative Commons license terms for re-use do not apply to any content

(such as graphs, figures, photos, excerpts, etc.) not original to the Open Access publication and further permission may be required from the rights holder. The obligation to research and clear permission lies solely with the party re-using the material.

This book is available for free download in the Open Access section of the publishers' website. (https://doi.org/10.53179/9783868933956).

A print version is available for a fee from the publisher.

The page numbers in the print and in the online version are identical.

(C) EB-Verlag Dr. Brandt

Berlin, 2020

Coverdesign: (C) Rainer Kuhl, Berlin

ISBN 978-3-86893-356-7 (Print)

ISBN 978-3-86893-395-6 (Open Access)

DOI 10.53179/9783868933956 


\section{At the Intersection of Labour History and Digital Humanities: What Vaguely Described Work Can Tell Us about Labour Relations in the Past*}

\section{Introduction}

To survive, human beings depend on activities we commonly call "work." Such activities create social relations between people that can involve power and dependency, often because the control of productive resources (such as land) are not equally distributed in society. The most extreme form of dependency rooted in work is slavery. Lack of the physical and mental capacities to support oneself creates other forms of dependency. The need to sustain oneself and its ensuing entanglements with others have, over time, formed a persistent nexus between work, power, and dependency.

What it means to depend upon someone else varies. Analysing witness statements in early modern England, Alexandra Shepard has shown, for instance, that relying "on others could [...] be a source of status as well as discredit." While it was often regarded as a sign of wealth and respectability for a married woman to be supported by her husband, the same was not true for a married man supported by his wife. Receiving charity from someone else did not improve one's social standing either. ${ }^{1}$ These examples show that the context in which people describe themselves as economically dependent on someone else is crucially important to how we should understand such statements. Other types of historical data such as descriptions of work activities (e.g., "painting" or "mowing") also require contextualisation. What might look like the same work activity can mean different things depending upon the conditions under

* This article is a revised version of a paper given first in Vienna and then at the inauguration ceremony of the Bonn Center for Dependency and Slavery Studies, 7 November 2019. I am grateful to Jane Whittle and to the GaW research group for their comments on an earlier version.

1 Alexandra Shepard, Accounting for Oneself. Worth, Status, \& Social Order in Early Modern England (Oxford, New York: Oxford University Press, 2015), 194. 
which it is carried out. Knitting stockings for your own use is quite different to knitting stockings that you plan to sell on a market. Knitting stockings in a factory for a wage is, again, different, and so is knitting stockings for your owner if you are a slave. The many interpretations of what it means to depend on someone for one's living and the highly contextualized character of work do not at first inspire hope that the nexus between work and dependency is a suitable topic for automatic, computer-aided analysis.

In this article, however, I explore this nexus against the backdrop of two recent developments in historical scholarship. The first development is the revitalised interest in labour relations across time and space exemplified, for instance, by the Bonn Center for Dependency and Slavery Studies. ${ }^{2}$ The second development is the increasing interest in, and reliance on, new digital technologies for analysing large amounts of historical data, often discussed as "big data" or "digital humanities." 3 The new technologies are promising, but the volume of historical documents remains daunting and requires efficient methods. A challenge for historians who want to mine texts for information expressed in words, not numbers, is the different meanings behind similar linguistic expressions. This challenge forces historians to think along new lines and to cooperate across disciplines. A discipline of key interest is computer linguistics.

The study presented here does not rely on computer-aided tools, but was carried out with the help of traditional, manual analysis. Its primary purpose was to identify linguistic markers that might be useful for extracting information about work and working conditions. In a longer-time perspective, such markers might assist historians in processing large numbers of early modern documents. To decide whether or not the proposed markers perform well, the results have to be compared with what we already know about early modern working life. This study is therefore explorative and methodological rather than empirical; arriv-

2 www.dependency.uni-bonn.de. See also the COST Action "Worlds of Related Coercions in Work" (WORCK, CA 18205) and Jane Whittle's ERC project "Forms of Labour: Gender, Freedom and Experience of Work in the Preindustrial Economy."

3 See, e.g., Melissa Terras, Julianne Nyhan, and Edward Vanhoutte, Defining Digital Humanities: A Reader (Farnham: Ashgate, 2013); Jo Guldi and David Armitage, The History Manifesto (Cambridge: Cambridge University Press, 2014). 
ing at results similar to those reached using traditional methods will be seen as confidence-inspiring rather than disappointing. Taking the time to develop new methods and replicating results are often advocated in science, but they are seldom applied. ${ }^{4}$

For the sake of clarification, I want to stress that I discuss only those dependencies linked to work, not those that arise from dependency on alms or married women's traditional economic dependency on their husbands. Instead, I focus on women and men who worked to support themselves in occupations often described only vaguely in the sources, but accompanied by information relevant to our understanding of labour relations. The definition of "labour relations" applied here is that proposed by Karin Hofmeester and others at the International Institute of Social History: "with and for whom you work and under what rules." This definition captures the nexus between work and dependency and suggests ways to operationalize and study it.

When the concept "gender" is used in the article, it refers to the distinction between women and men observed in historical records as performers of work. In the analysis, the distinction was established with the help of linguistic markers such as personal names and personal pronouns. While some of the cases provide rich and clear information on work activities and labour relations, in most cases the evidence is brief, fragmentary, and messy. Sometimes, all we know about a person is that "she" performed some form of work. But the messy and fragmentary character of sources is something historians have always had to handle; new technologies may help us to handle it better.

In the following section, I discuss the different types of data historians use to discuss work. In the next two sections, I will present a set of verbs and verb phrases that describe work, in admittedly vague terms, but that provide useful information about labour relations. In the fourth

4 Lee McIntyre, The Scientific Attitude. Defending Science from Denial, Fraud, and Pseudoscience (Cambridge, London: MIT Press, 2019), 105-112, 189.

5 Karin Hofmeester, Jan Lucassen, Leo Lucassen, Rombert Stapel, and Richard Zijdeman, "The Global Collaboratory on the History of Labour Relations, 1500-2000: Background, Set-Up, Taxonomy, and Application," International Institute of Social History, 26 October 2015, quote from p. 6; https://collab.iisg.nl/web/labourrelations (downloaded 20200904, 10:37). 
section after this introduction, I suggest a number of markers or indicators (words and collocations of words) that can be used to mine historical documents for more concrete information on labour relations. In the conclusion, I compare the empirical results with some of what is already known about labour relations in the past.

\section{Types of data used in the history of work}

When historians work with computer linguists, it is helpful for both parties to identify the sorts of information historians need to answer their questions and the linguistic form that information will take. Both historians and linguists use texts. The historian is most interested in the content of the text, but it is worth remembering that texts also have certain forms and contain certain grammatical components.

For the history of work, historians have relied upon five main types of data: wages, occupational descriptors, work activities, material objects, and labour relations, each of which has yielded a specific historiographical field. Using wage data, scholars like Robert Allen, Jane Humphries, and others have researched and debated whether or not there was a high wage economy in Britain prior to the Industrial Revolution. ${ }^{6}$ Wage data often take a numerical form, but historical wage data can also include strings of words. For instance, it was common in the early modern period to pay workers with shoes and textiles. Using occupational descriptor data, the Cambridge Group for the History of Population and Social Structure has mapped and analysed sectoral shifts in the economy and, by extension, contributed to our understanding of economic development. ${ }^{7}$ Occupational descriptors are nouns such as

6 For instance, Robert Allen, "The High Wage Economy and the Industrial Revolution: A Restatement," Economic History Review 68 (2015): 1-22; Jane Humphries and Jacob Weisdorf, "The Wages of Women in England, 1260-1850," Journal of Economic History 75 (2015): 405-47; Jane Humphries and Benjamin Schneider, "Spinning the Industrial Revolution," Economic History Review 72 (2019): 126-55; Kathryn E. Gary, Work, Wages and Income. Remuneration and Labor Patterns in Sweden 1500-1850 (Lund: Lund University, 2018).

7 Leigh Shaw-Taylor and E. A. Wrigley, "Occupational structure and population change," in The Cambridge Economic History of Modern Britain, Vol. 1: Industrialisa- 
carpenter, miller, and seamstress found in baptismal records and other texts. Using work activity data, scholars like Sheilagh Ogilvie, Jane Whittle, Mark Hailwood, and the Gender and Work Group (which I represent) have contributed to our understanding of the gender division of work. ${ }^{8}$ Work activity data typically take the form of a verb phrase consisting of a verb and a direct object that together describe the work task in question such as make charcoal, pick lice from someone, steal clothes, deliver letters, wash floors, transport timber. Information on possession of material objects (from probate inventories) used by scholars to measure the importance of by-employment and pluriactivity typically takes the form of nouns such as plough or spindle ${ }^{9}$ Jan de Vries famously combined wage data and probate inventory data to claim that there was an "industrious revolution" prior to the Industrial Revolution. ${ }^{10}$ Finally, the sources of labour relations data are many and cannot be described here exhaustively, but labour legislation, censuses, and records of employer/ employee litigations have provided important information. ${ }^{11}$ Litigation cases lend themselves excellently to qualitative analysis, but as yet it is more difficult to identify the exact grammatical components of interest in such cases.

tion, 1700-1870, eds. Roderick Floud, Jane Humphries, and Paul Johnson (Cambridge: Cambridge University Press, 2014): 53-88.

8 Sheilagh Ogilvie, A Bitter Living. Women, Markets, and Social Capital in Early Modern Germany (Oxford, New York: Oxford University Press, 2003); Jane Whittle and Mark Hailwood, "The Gender Division of Labour in Early Modern England," Economic History Review 73 (2020): 3-32; Maria Ågren, ed. Making a Living, Making a Difference: Gender and Work in Early Modern European Society (Oxford, New York: Oxford University Press, 2017).

9 For instance, Mark Overton, Jane Whittle, Darron Dean, and Andrew Hann, Production and Consumption in English Households, 1600-1750 (London, New York: Routledge, 2004); Sebastian A. J. Keibeck and Leigh Shaw-Taylor, "Early Modern Rural By-Employments: A Re-Examination of the Probate Inventory Evidence," Agricultural History Review 61 (2013): 244-81. On the importance of multiple employment, see also Keith Thomas, The Ends of Life. Roads to Fulfilment in Early Modern England (Oxford, New York: Oxford University Press, 2009), 106, and Shepard, Accounting for Oneself, 232-6.

10 Jan de Vries, "The Industrial Revolution or the Industrious Revolution," Journal of Economic History 54 (1994): 249-70.

11 Hanne Østhus, "Contested Authority: Master and Servant in Copenhagen and Christiania, 1750-1850," (unpublished Ph.D. thesis, European University Institute, Florence, 2013); Hanne Østhus, "Servants in Rural Norway, ca. 1650-1800," in Servants in Rural Europe 1400-1900, ed. Jane Whittle (Woodbridge: The Boydell Press, 2017): 113-30. 
The Swedish Gender and Work Project studies what women and men did to support themselves in Sweden from 1550 to 1880. For this purpose, we have chosen to use work activity data, i.e., data on what people did to support themselves, as our key type of information using what we call the verb-oriented method. To date (September 2020), we have more than 38,000 observations, culled primarily from court records, but also from accounts, petitions, diaries, and tax registers. The observations/ verb phrases are sorted into 16 different sub-datasets (e.g., agriculture and forestry, crafts and construction, care, and managerial work) and stored in a purpose-built database. Although the verb phrases describing work are the core data in the database, each verb phrase has been tagged with a number of metadata such as sex and marital status of the person who performed the activity, the time and place of the activity, and other factors. ${ }^{12}$

Table 1 gives some concrete examples of what the verb-oriented method yields. It shows that both men and women worked, which is unsurprising. More importantly, it pinpoints their exact tasks. Even more interestingly, the table illustrates that while some tasks seem to have been gender-specific, there was also a considerable overlap between the sexes. If we take, for instance, forms of care work (marked in italics in the table), we see only men described as shaving others and only women described as picking lice from others, but both men and women bandaged wounds.

12 Maria Ågren, "Introduction: Making a Living, Making a Difference," in Making a Living, Making a Difference: Gender and Work in Early Modern European Society, ed. Maria Ågren (Oxford, New York: Oxford University Press, 2017): 1-23, esp. 13-9. 
Table 1. Examples of verb phrases describing women's and men's work in Sweden, 1550-1800. Verb phrases in italics describe care work. Total number of observations: 12,231 .

\begin{tabular}{|l|l|}
\hline Men only & $\begin{array}{l}\text { make charcoal; shave somebody; make shoes; lend grain; keep } \\
\text { inn; order transportation; buy share of ship; freight iron; ring } \\
\text { bells }\end{array}$ \\
\hline Both sexes & $\begin{array}{l}\text { harvest hay; bandage wounds; build house; lend money; serve } \\
\text { food; send somebody; lease out horse; drive sleigh; wash clothes }\end{array}$ \\
\hline $\begin{array}{l}\text { Women } \\
\text { only }\end{array}$ & $\begin{array}{l}\text { milk cow; pick lice from someone; weave; pay spouse's debts; } \\
\text { pluck geese; manage store; sell beef; fetch water; clean }\end{array}$ \\
\hline
\end{tabular}

Source: Jonas Lindström, Karin Hassan Jansson, Rosemarie Fiebranz, Benny Jacobsson, and Maria Ågren, “Mistress or maid: the structure of women's work in Sweden, 1550-1800," Continuity and Change 32 (2017), 225-52, Tables 1 and 2. Comment: All translations of Swedish text in this table and throughout the article are by the author.

There are a number of advantages to using work activity data. Contrary to wage data, work activity data capture both paid and unpaid work, which is important if we study societies with low occupational specialization and/or if we want to capture women's work. Work activity data are also more direct, similar to observations of work, than more indirect occupational descriptors that scholars assume serve as a proxy for the work activities that people actually carried out. Moreover, sufficient amounts of activity data lend themselves to time-use studies, which the UN and the World Bank advocate for studies of world economic development. ${ }^{13}$ Finally, it has been argued that pre-modern societies were task-oriented rather than occupation-oriented. In such societies, it would be anachronistic to proceed from the assumption that work can be conceptualised and studied as discrete occupations. ${ }^{14}$ People were seldom specialists but combined various sources of income to survive.

13 Valeria Esquivel, Debbie Budlender, Nancy Folbre and Indira Hirway, "Explorations: Time-use Surveys in the South," Feminist Economics 14 (2008): 107-52.

14 E.P. Thompson, "Time, Work-Discipline, and Industrial Capitalism," Past and Present 38 (1967): 56-97, esp. 60, 71. 
Activity data, however, also have some drawbacks. Most importantly, they are evidence of occurrence rather than frequency. If we find evidence in a court record of a woman selling cabbage, we can draw the conclusion that selling cabbage was a work activity she engaged in, but we do not know if this was her main work activity and source of income, or just something that she did once that happened to be described in the record. Another drawback is the multiple meanings that can hide behind the same work activity description. The example of knitting (mentioned at the beginning of this article) illustrates this point: verb phrases do not in and of themselves divulge what sort of labour relation is involved.

Using two subsets of data collected within the Gender and Work Project, I delve deeper into these questions. As already stated, the primary purpose of the study was to find linguistic markers of labour relations that might be useful in a more large-scale study. The first subset was designed with a view to finding data on work carried out by people in subordinate positions. It consists of 733 observations of work activities from 1550 to 1880 culled from court records, tax registers, accounts, diaries, and petitions (Tables 2, 3, and 4). Typical of this subset is the vagueness of the verb phrases, the availability of contextual information, and the relatively good gender balance: 57 per cent of the observations described work by men, and 43 per cent work by women. Work data collected using a verb-oriented approach generally have a lower share of female work activities. ${ }^{15}$

Since the analysis presented here was carried out manually, not computer aided, a larger subset would have been impossible to handle. If the whole GaW database had been used, the difference would have been that most verb phrases were more specific in their descriptions of the work activity, but the gender balance would have been much more skewed towards activities by men. For the purpose of this analysis, the contextual information was particularly important, and it is unlikely that

15 See figures for Württemberg (33\% female activities), for five counties in south-west England (29\% female activities), and for various parts of Sweden (25\% female activities). Ogilvie, Bitter Living, 25; Whittle and Hailwood, "The Gender Division of Labour," 11; Ågren, "Introduction," 14-6. See also Shepard, Accounting for Oneself, 17 , whose dataset includes nearly 25 per cent women. Shepard's method is similar to those used in the three former studies. 
the 733 observations were radically different in this respect from the database as a whole.

The second subset of data was designed to find verb-phrase data on work carried out by people in leading positions (Table 5). It consists of 101 observations of work activities from 1638 to 1826 culled mainly from court records (86 of 101 observations). The data show 82 per cent activities by men and 18 per cent activities by women. Typical of these verb phrases were their vague descriptions of work, all of which included the Swedish verb låta (let or have, as in have someone do something). The whole database was searched to identify these verb phrases. ${ }^{16}$

\section{Vaguely described work by people in subordinate positions}

The activities in the first subset were typically described in the sources as working, serving, or helping. The descriptions could be even vaguer, and some simply state that someone had been in a specific place at a certain point in time. These observations are very different from phrases such as harvest oats, classified as an agricultural activity, or make shoes, a craft activity. In fact, such vague descriptions of work were no more informative than occupational descriptors such as labourer and worker, which say nothing about whether the person worked in agriculture, handicrafts, industry, or the tertiary sector. Both work and worker leave the actual work unspecified. ${ }^{17}$

16 GaW Database, Uppsala University, 2020-09-08, 15.43. Search criteria: (Godkända fall): "Kön" = 'Man' AND "Verbfras (källa)" = "*låta*”; (Godkända fall): "Kön" = 'Kvinna' AND "Verbfras (källa)" = '*låta*.' If *låt* rather than *låta* (infinitive) had been used, the search would have yielded more examples: 318 male activities and 90 female activities. However, such a search would also have yielded many false positives, as I explain below.

17 In the GaW data analysed and published in 2017, unspecified work made up 4\% of all work activities. Jonas Lindström, Rosemarie Fiebranz, and Göran Rydén, "The Diversity of Work," in Making a Living, Making a Difference: Gender and Work In Early Modern European Society, ed. Maria Ågren (Oxford, New York: Oxford University Press, 2017): 24-56, esp. 31. 
When people talked about work without specifying it in terms of tasks, what did they talk about instead? This question prompts us to look more closely at the words surrounding the work verb. Sometimes, such an inspection may clarify the sort of task the unspecific verb phrase must have referred to. On its own, the Swedish verb syssla (to perform tasks or chores) is vague, but with the added information that the activity took place in a cowshed, the case may be seen as an example of agricultural work. In other cases, however, the surrounding words say little about the work task itself. Nevertheless, these observations offer other incidental details that make them useful.

The subset includes people talking about both their own work and other people's work using vague verbs, but including additional incidental information. It was not possible to distinguish systematically between these cases in the analysis, and it may not be that important to do so. External characterizations influence how groups define themselves, and it is likely that this operates on the individual level as well. For example, if we keep referring to a man as a painter, this will likely affect how he looks upon and describes himself. External characterization affects selfcharacterization. ${ }^{18}$

The observations of vaguely described work were sorted according to the types of information used in the sources to define the work activity (Table 2). In this way, the categories are built from the bottom up: they reflect how work was talked about at the time in the 733 cases. The majority of cases are from 1601 to 1800 (Table 3), culled mostly from court records (Table 4).

18 On self-descriptions and how historians can study them, see Shepard, Accounting for Oneself, 1-32. On external characterizations and their effects on groups, see Mark Hailwood, “The Honest Tradesman's Honour': Occupational and Social Identity in seventeenth-century England," Transactions of the Royal Historical Society 24 (2014): 79-103, and Karin Hassan Jansson, "Pigors arbete och vardag i det tidigmoderna Sverige", Personhistorisk Tidskrift 109 (2013): 137-58. For a more general discussion of how external categorization affects identity, see Ian Hacking, "Making Up People" in Ian Hacking, Historical Ontology (Cambridge, London: Harvard University Press, 2002): 99-114. 
Table 2. Types of contextual information in cases where the work activity was vaguely described

\begin{tabular}{|c|c|c|c|c|}
\hline $\begin{array}{l}\text { Type of contextual } \\
\text { information offered } \\
\text { in the source }\end{array}$ & $\begin{array}{l}\text { Male work } \\
\text { (n) }\end{array}$ & $\begin{array}{l}\text { Female work } \\
\text { (n) }\end{array}$ & $\begin{array}{l}\text { Male and } \\
\text { female }(\mathrm{N})\end{array}$ & $\begin{array}{l}\text { Male and female } \\
\text { (per cent) }\end{array}$ \\
\hline $\begin{array}{l}\text { For whom the work } \\
\text { was performed }\end{array}$ & 192 & 165 & 357 & 34 \\
\hline $\begin{array}{l}\text { What income the } \\
\text { work (should have) } \\
\text { generated }\end{array}$ & 94 & 89 & 183 & 17 \\
\hline $\begin{array}{l}\text { The contractual } \\
\text { terms under which } \\
\text { the work took } \\
\text { place }\end{array}$ & 111 & 54 & 165 & 16 \\
\hline $\begin{array}{l}\text { Where the work } \\
\text { took place }\end{array}$ & 82 & 35 & 117 & 11 \\
\hline $\begin{array}{l}\text { Concrete and/or } \\
\text { emotional descrip- } \\
\text { tions of work }\end{array}$ & 31 & 43 & 74 & 7 \\
\hline $\begin{array}{l}\text { Duration of the } \\
\text { work }\end{array}$ & 40 & 23 & 63 & 6 \\
\hline $\begin{array}{l}\text { When work took } \\
\text { place }\end{array}$ & 13 & 24 & 37 & 3 \\
\hline Occupational title & 16 & 19 & 35 & 3 \\
\hline $\begin{array}{l}\text { With whom the } \\
\text { work was carried } \\
\text { out }\end{array}$ & 11 & 12 & 33 & 3 \\
\hline Being there & 3 & 4 & 7 & $<1$ \\
\hline $\begin{array}{l}\text { TOTAL descriptions } \\
\text { in the cases }\end{array}$ & 593 & 468 & 1061 & 100 \\
\hline TOTAL cases & 420 & 313 & 733 & $57 / 43$ \\
\hline
\end{tabular}

Source: GaW database accessed 1 November 2019. Information from Gripsholm, Julita, Umeå, Luleå excluded.

Comments: Since an observation of unspecified work could come with more than one piece of contextual information (average 1.4 descriptions per case), the number of descriptions is higher than the number of cases. It was not always easy to distinguish the category contractual terms from the category for 
whom the work was performed, as the latter might also indicate a contractual relationship. Contractual terms were used when the relationship was described in a more formal and less personal way. "Being there" captures observations of people described as being in a particular place in a way that suggests that they may have worked in that place.

Table 3. Observations of vaguely described work per sex and time period

\begin{tabular}{|l|l|l|l|}
\hline & $\begin{array}{l}\text { Female } \\
\text { unspecified work }\end{array}$ & $\begin{array}{l}\text { Male } \\
\text { unspecified work }\end{array}$ & TOTAL \\
\hline $1555-1600$ & 1 & 4 & 5 \\
\hline $1601-1700$ & 137 & 218 & 355 \\
\hline $1701-1800$ & 138 & 99 & 237 \\
\hline $1801-1880$ & 37 & 99 & 136 \\
\hline TOTAL & 313 & 420 & 733 \\
\hline
\end{tabular}

Source: Table 2.

Table 4. Observations of vaguely described work per sex and source type

\begin{tabular}{|l|l|l|l|}
\hline & $\begin{array}{l}\text { Female unspeci- } \\
\text { fied work }\end{array}$ & $\begin{array}{l}\text { Male } \\
\text { unspecified work }\end{array}$ & TOTAL \\
\hline Court records & 225 & 304 & 529 \\
\hline Tax registers & 39 & 33 & 72 \\
\hline Accounts & 12 & 57 & 69 \\
\hline Diaries & 33 & 17 & 50 \\
\hline Petitions & 4 & 9 & 13 \\
\hline TOTAL & 313 & 420 & 733 \\
\hline
\end{tabular}

Source: Table 2.

As Table 2 shows, it was most common for vaguely described work to be mentioned together with the person for whom the work was carried out (34\%). This was true for both women and men. One woman was described as "a maidservant who served Ingel Håckansson," another "served Håkann Biörnsson," a third "served Johan Ertz," and many were 
described as being "in his service." ${ }^{19}$ Likewise, one man was described as being "a young male servant serving [...] Hanns von Massenbach," another said he had "served Hauptman Thore Ollsson," and a third was said to have "served Per Larsson Belgmakare [bellows maker]."20 Many of these cases described the work of young people in a subordinate position or in military service. However, men who were more established in local society could also talk about their work in vague terms and with an emphasis on the person they served. For instance, one man who held a minor state office described what had happened "when he was about to carry out his office for the Crown." 21 The person for whom the activity was performed was often the master or mistress of the household, which is unsurprising in view of the small-scale and rural character of most production units in early modern Sweden.

But information about for whom work had been carried out could also describe other types of beneficiaries such as the worker's family or relatives. In these cases, work was described primarily as a social relationship between two specific persons, a relationship that did not necessarily have an asymmetrical character. For example, two Stockholm women said in 1733 that they did their work to "support our poor husbands." 22 It is possible - indeed likely - that this phrase alluded to contemporary ecclesiastical legislation that emphasised the moral obligation of spouses to support one another, but it can also be read as a reference to particular royal statutes stressing the obligations and

19 GaW Database, Uppsala University, 2020-03-17 13:47:59, case 161 (original source: Vadstenas landsarkiv, Göta hovrätt, EVAA, 46); GaW Database, Uppsala University, 2020-03-17 13:50:00, case 541 (original source: Vadstenas landsarkiv, Göta hovrätt, EVAA, 38); GaW Database, Uppsala University, 2020-03-17 13:51:04, case 581 (original source: Vadstenas landsarkiv, Göta hovrätt, EVAA, 51).

20 GaW Database, Uppsala University, 2020-03-17 13:52:26, case 1141 (original source: Stockholms stadsarkiv, Borgmästare och Råd före 1636, A, 32); GaW Database, Uppsala University, 2020-03-17 13:53:29, case 1401 (original source: Vadstenas landsarkiv, Göta hovrätt, EVAA, 48); GaW Database, Uppsala University, 2020-03-17 13:55:29, case 7477 (original source: Uppsalas landsarkiv, Söderbärke tingslags häradsrätt, A I, 5).

21 GaW Database, Uppsala University, 2020-03-17 13:56:49, case 4054 (original source: Uppsalas landsarkiv, Stora Malms kyrkoarkiv, K I, 1).

22 GaW Database, Uppsala University, 2020-03-17 13:57:48, case 9232 (original source: Stockholms stadsarkiv, Handelskollegium, E VII, 1). 
duties of wives. ${ }^{23}$ A married man who was in custody was described as being temporarily unable to "support her" (i.e., his wife), and steps were taken to alleviate her situation. ${ }^{24}$ The reference to a husband's duty to support his wife was more uncommon in the Swedish material than in that from England; ${ }^{25}$ however the GaW database does contain more than one example. Another man was said to "work at home at his parents' [place]." 26 All of these cases describe working for family members within a family context.

There are also examples of women's work being described in terms of helping others. When an informer reported that Kirstin Jonsdotter was not in service as young people should be, the local court declared her not guilty as she was taking care of her old mother and, in addition, "assists her brother Anders with the work [at the farm]."27 It was not only when women worked in a family context that their work was defined as helping. Often, married women who worked in the households of others seem to have preferred to talk about their work as helping rather than serving. In this way, they suggested that their work was part of a more symmetrical social relationship. ${ }^{28}$ The language of helping was not exclusive to women's work, however, as men's work could also be described in terms

23 See the Swedish ecclesiastical legal code of 1686 (1686 års kyrkolag). See also Marie Lennersand, Jan Mispelaere, Christopher Pihl, Maria Ågren, "Gender, Work, and the Fiscal-Military State," in Making a Living, Making a Difference: Gender and Work in Early Modern European Society, ed. Maria Ågren (Oxford, New York: Oxford University Press, 2017): 178-203, esp. 188-92.

24 GaW Database, Uppsala University, 2020-03-17 13:58:56, case 10167 (original source: Riksarkivet, Svea Hovrätt, Advokatfiskalens arkiv EXIe, 2289). This case is discussed briefly in Maria Ågren, "Conclusion," in Making a Living, Making a Difference: Gender and Work in Early Modern European Society, ed. Maria Ågren (Oxford, New York: Oxford University Press, 2017): 204-220. Cf. GaW Database, Uppsala University, 202003-17 14:00:12, case 12746 (original source: Uppsala universitetsbibliotek, Anna Greta Veiland, 1, X 315) and GaW Database, Uppsala University, 2020-03-17 14:01:19, case 14709 (original source: Uppsalas landsarkiv, Västerås rådhusrätt och magistrat, A II, 89).

25 Shepard, Accounting for Oneself, 214-31.

26 GaW Database, Uppsala University, 2020-03-17 14:02:19, case 14853 (original source: Uppsalas landsarkiv, Västerås rådhusrätt och magistrat, A II ca, 2).

27 GaW Database, Uppsala University, 2020-03-17 14:03:22, case 5483 (original source: Vadstenas landsarkiv, Östra häradsrätts arkiv, AI a, 18).

28 Maria Ågren, “Emissaries, Allies, Accomplices and Enemies: Married Women's Work in Eighteenth-Century Sweden," Urban History 41 (2014): 394-14. 
of help and assistance. For example, one man was described as "helping" a widow "with her work." 29 The word help had broader connotations in the early modern period than it has today. It could refer to activities carried out by dependent and subordinate people, but it could also refer to less hierarchic relations. There are for instance 18th-century government statutes ordering the different branches of the state administration to "lend each other a helping hand," which was another way of saying that they should join forces and work more efficiently. ${ }^{30}$ Here, help meant cooperation. In other cases, the use of the word help emphasized the temporary character of the helping activity; it was not the person's normal work. Descriptions of work in terms of help are ambiguous, and a larger systematic analysis would be welcome. ${ }^{31}$

Table 2 also shows that several other forms of contextual information could be offered together with a vague work verb. The second and third most common categories had to do with income from work or with the labour contract, but before going into these two types I want to discuss three smaller categories that were often similar to the for whom cases. In 11 per cent of the descriptions, information focused on where the work had taken place. Examples of this construction are "she served in [the village] Nijlösa" and "a little girl served at the farm."32 One man was described as being away for work "far from the village."33 Alternatively, information on the duration of the work could be added (as in $6 \%$ of the descriptions). For example, a woman was described as having

29 GaW Database, Uppsala university, 2020-03-17 14:04:31, case 4471 (original source: Vadstenas landsarkiv, Östra häradsrätts arkiv, AI a, 4).

30 Maria Ågren, The State as Master. Gender, State Formation and Commercialisation in Urban Sweden, 1650-1780 (Manchester: Manchester University Press, 2017), 144.

31 See also the discussion about men helping out in the cowshed in Ann-Catrin Östman, Mjölk och jord. Om kvinnlighet, manlighet och arbete i ett österbottniskt jordbrukarsamhälle ca 1870-1940 (Åbo: Åbo Akademis Förlag, 2000), 224-43.

32 GaW Database, Uppsala university, 2020-03-17 14:05:39, case 41 (original source: Vadstenas landsarkiv, Göta hovrätt, EVAA, 1); GaW Database, Uppsala university, 2020-03-17 14:06:49, case 1401 (original source: Vadstenas landsarkiv, Göta hovrätt, EVAA, 48).

33 GaW Database, Uppsala University, 2020-03-17 14:08:02, case 10551 (original source: Riksarkivet, Svea Hovrätt, Advokatfiskalens arkiv EXIe, 2262). 
"served for one and a half year." 34 A man described how he had worked for eight years without having received payment, and now demanded to be paid by the man who had married his deceased employer's widow, arguing that this man had to take responsibility for the debt as he had taken responsibility for the widow. ${ }^{35}$ A third alternative was to indicate a specific point in time when work had taken place (as in 3\% of the descriptions). A man was said to have served "for her [the mistress's late mother]," which was to contemporaries a precise chronological indication. ${ }^{36}$

These types of information could also be combined, as when a woman was said to have "served Nils Håkonsson in Näs for six years" (for whom, where, and duration) or "she served a potter in our town" (for whom, where). ${ }^{37} \mathrm{~A}$ man from the Sami population was said to have "done some work for Erik Olofsson in Ede at that time" (for whom, where, when). ${ }^{38}$ In total, 217 observations (20\% of all activities in Table 2) described work in terms of place, time, or duration. In many of these cases, mentioning a place - a farm, a village, a town - was probably an alternative to mentioning the master or mistress by name because they would have been strongly associated with the place. We may be justified in looking upon the four categories of for whom, when, where, and duration as essentially the same type of information. They said little about concrete work tasks but more about the social and geographic context. Together, they made up 54\% of all descriptions added to vaguely defined work phrases. Many of these descriptions came from the court records.

The second most common way of specifying vaguely described work was to focus on the remuneration it generated - or should have gener-

34 GaW Database, Uppsala University, 2020-03-17 14:08:53, case 5262 (original source: Stockholms stadsarkiv, Stadens kämnärsrätt, A2A, 43).

GaW Database, Uppsala University, 2020-03-17 14:09:29, case 7246 (original source: Uppsalas landsarkiv, Örebro rådhusrätt och magistrat, A 1 A, 16).

36 GaW Database, Uppsala University, 2020-03-17 14:10:29, case 9978 (original source: Uppsalas landsarkiv, Snevringe häradsrätt, A I a, 5).

37 GaW Database, Uppsala University, 2020-03-17 14:11:21, case 1502 (original source: Uppsala universitetsbibliotek, Westinska samlingen, W, W 483); GaW Database, Uppsala University, 2020-03-17 14:11:58, case 361 (original source: Vadstenas landsarkiv, Göta hovrätt, EVAA, 23).

38 GaW Database, Uppsala University, 2020-03-17 14:12:44, case 7707 (original source: Östersunds landsarkiv, Jämtlands domsagas häradsrätts arkiv, A I, 11). 
ated - for the worker (17\% in Table 2). Here, work was talked about, not as concrete tasks, but as sources of income. There are examples of men who were "promised two barrels of corn" or "three pairs of stockings" or who "received 30 silver daler from the town."39 Similarly, women could talk about their own work in terms of monetary income or go to court to claim unpaid wages for servant work. Widows also claimed their deceased husbands' outstanding wages for work. ${ }^{40}$ These cases might indicate how work spawned legal conflicts between master and servant, employer and employee, but this was not necessarily the case. Many of the descriptions mentioning income came from account books or other sources produced by the tax administration, so they merely stated that payment was due or had been received. ${ }^{41}$

The third most common way of specifying vaguely described work was to talk about the conditions to which the implicit or explicit contract exposed the worker (16\% in Table 2). In these cases, the sources discuss, for instance, when the employment began, when it ended, or for how long it had been going on. Again, this could be because there was some kind of conflict between the employer and the employee (e.g., when a court record said of a man that he had "unlawfully left his [master's]

39 GaW Database, Uppsala University, 2020-03-20 08:49:18, case 7506 (original source: Östersunds landsarkiv, Jämtlands domsagas häradsrätts arkiv, A I, 11); GaW Database, Uppsala University, 2020-03-20 08:50:41, case 9032 (original source: Stockholms stadsarkiv, Stadens kämnärsrätt, A1A, 8); GaW Database, Uppsala University, 2020-03-20 08:51:29, case 7684 (original source: Riksarkivet Helsingfors, Ekenäs rådstuvurätt, D, 1).

40 GaW Database, Uppsala University, 2020-03-17 14:17:19, case 5234 (original source: Stockholms stadsarkiv, Stadens kämnärsrätt, A1A, 8); GaW Database, Uppsala University, 2020-03-17 14:18:04, case 2962 (original source: Uppsalas landsarkiv, Örebro rådhusrätt och magistrat, $\mathrm{A} 1 \mathrm{~A}, 60)$; GaW Database, Uppsala University, 202003-17 14:18:48, case 3121 (original source: Uppsalas landsarkiv, Örebro rådhusrätt och magistrat, A 1 A, 60); GaW Database, Uppsala university, 2020-03-17 14:19:38, case 10168 (original source: Evangeliska Brödraförsamlingens arkiv, Stockholm, Erland och Cristina Charlotta Hiärnes arkiv, Bergsrådinnan Chr Charl. Hiärnes Kassabok 1788-1795, nr 14); GaW Database, Uppsala University, 2020-03-17 14:20:30, case 12795 (original source: Uppsala universitetsbibliotek, Anna Greta Veiland, 1, X 315).

41 Many of these observations were culled from Stockholm's mantalslängder (approximately poll tax registers) where the focus was on whether or not people could support themselves, i.e., whether or not they had an income. To some degree, this source provides concrete descriptions of work tasks, but sometimes it just confirms that someone did have an income from hjälparbete (assistance work). 
service.") ${ }^{42}$ Another reason to stress the contractual relationship was when a person served as a witness at court. It was important to ascertain whether or not the witness was still employed by one of the parties in the dispute, in which case the witness would have had an interest in the outcome of the suit. However, in many of these cases the information about the contract is very sparse and does not suggest a conflict. People were described as doing "day labour" (often in accounts), "casual work," or being employed by municipal authorities. ${ }^{43} \mathrm{~A}$ farmer described in his diary how he had "hired Jon Ols Erich as my farmhand." 44

People could also talk about with whom they had worked. In one case, a woman was described as working with a man while they were both "at Anders Anderson's" (presumably this should be read as "in Anders Anderson's service"). ${ }^{45}$ In other cases, a man and a woman were described as having "been together in service." 46 The context in which this sort of information surfaced was often in investigations into alleged fornication or other forms of sexual misconduct. When the accused parties were interrogated about their contacts with each other, they described how they had become acquainted when they worked together. Their need to support themselves had brought them into contact with

42 GaW Database, Uppsala University, 2020-03-17 14:21:28, case 7488 (original source: Uppsalas landsarkiv, Kopparbergs och Säters län (utom Säters socken) och Österdalarne tingslags häradsrätt, A I, 33).

43 GaW Database, Uppsala University, 2020-03-17 14:22:34, case 8267 (original source: Riksarkivet, Tidöarkivet, 6, 436); GaW Database, Uppsala University, 2020-03-17 14:23:21, case 11321 (original source: Uppsalas landsarkiv, Ramnäs bruk, G 2, 1); GaW Database, Uppsala University, 2020-03-17 14:24:21, case 17217 (original source: Uppsalas landsarkiv, Västerås rådhusrätt och magistrat, A II ca, 12); GaW Database, Uppsala University, 2020-03-17 14:25:08, case 17222 (original source: Uppsalas landsarkiv, Västerås rådhusrätt och magistrat, A II ca, 12); GaW Database, Uppsala University, 2020-03-17 14:25:47, case 18409 (original source: Uppsalas landsarkiv, Västerås rådhusrätt och magistrat, A II ca, 16); GaW Database, Uppsala University, 2020-0317 14:27:00, case 9247 (original source: Stockholms stadsarkiv, Handelskollegium, E VII, 1).

44 GaW Database, Uppsala University, 2020-03-20 10:05:08, case 7986 (original source: Länsmuseet Västernorrland, Per Edholms personarkiv, F1, 2).

45 GaW Database, Uppsala University, 2020-03-17 14:28:28, case 601 (original source: Vadstenas landsarkiv, Göta hovrätt, EVAA, 51).

46 GaW Database, Uppsala University, 2020-03-17 14:29:33, case 8199 (original source: Vadstenas landsarkiv, Göta hovrätt, B II a, 23). See also GaW Database, Uppsala University, 2020-03-17 14:30:34, case 14529 (original source: Uppsalas landsarkiv, Tuhundra häradsrätt, A 1 a, 28) 
each other. Three per cent of all descriptions say something about with whom people worked.

There are a number of hard-to-classify cases in which a person's work was described in a quite concrete, and even emotionally loaded, manner but with emphasis neither on the task itself nor on any labour relation. Instead, it was the concrete experience of work that was described in seven per cent of the cases (Table 2). Working women "worked with her hands," "did her chores," and "went there and did her work." A woman was said to "sit for herself" (as the Swedish source had it); a more idiomatic English translation would be that she fended for herself. In the German-speaking territories, this woman would probably have been referred to as an Eigenbrötlerin. ${ }^{47}$ Another woman who belonged to the higher echelons of society stated that "having no maid, I had to do everything myself." A woman from a lower social class was described as having "made herself useful in many ways" and having never been lazy. ${ }^{48}$ In this group of descriptions, we also find vivid expressions of how arduous work could be. The servant girl Margretha was said to serve in "daily toil and drudgery" (Swedish: dageliget sleet och släpe). ${ }^{49}$ Shepard reported similar descriptions of work in England: "gett[ing] his

47 Ogilvie, Bitter Living, 269-319.

48 GaW Database, Uppsala university, 2020-03-17 14:34:21, case 8566 (original source: Vadstenas landsarkiv, Göta hovrätt, E V ac, 65); GaW Database, Uppsala University, 2020-03-17 14:35:33, case 16636 (original source: Uppsalas landsarkiv, Västerås rådhusrätt och magistrat, A II ca, 22); GaW Database, Uppsala University, 2020-03-17 14:36:25, case 8208 (original source: Vadstenas landsarkiv, Göta hovrätt, EVAA, 63); GaW Database, Uppsala University, 2020-03-17 14:37:16, case 12747 (original source: Uppsala universitetsbibliotek, Anna Greta Veiland, 1, X 315); GaW Database, Uppsala university, 2020-03-17 14:38:06, case 8850 (original source: Stockholms stadsarkiv, Stadens kämnärsrätt, A1A, 37); GaW Database, Uppsala University, 2020-03-17 14:38:49, case 8851 (original source: Stockholms stadsarkiv, Stadens kämnärsrätt, A1A, 37); GaW Database, Uppsala University, 2020-03-17 14:39:29, case 1401 (original source: Vadstenas landsarkiv, Göta hovrätt, EVAA, 48); GaW Database, Uppsala University, 2020-03-17 14:40:28, case 9354 (original source: Evangeliska Brödraförsamlingens arkiv, Stockholm, Erland och Cristina Charlotta Hiärnes arkiv, Bergsrådinnan Chr Charl. Hiärnes Dagbok 1 jan 1744 - 8 maj 1747, del I); GaW Database, Uppsala University, 2020-03-17 14:41:19, case 10899 (original source: Uppsalas landsarkiv, Österdalarne och Gagnefs sockens tingslags häradsrätt, A I, 5). 
living with his handes," "hyr owne hand worke \& labor," and "by the labour of her hands and hath neither house or mayntenance."50

A clear example of a vague and yet still concrete description of work can be found in a case from 1695. The Swedish verb phrase is göra skäl för maten, which might be translated as "earn his daily bread." The phrase was found in a court record of a discussion of how the orphaned son of a soldier was to be brought up and supported. An arrangement was already in place: one local farmer was giving him "food and care" and teaching him to read, while another one provided him with clothing. The boy's inheritance covered these costs. When the matter was brought up for discussion again, it was because the court considered that the two farmers should no longer receive as much payment as they used to. This was because the boy was now old enough to work and thus "earn his daily bread." 51 The verb phrase is vague - we do not learn anything about what the boy's work consisted of - but it says a great deal about the social expectation that everyone should contribute to his upkeep.

Finally, there are a few cases $(<1 \%$ in Table 2 ) with no work of any kind mentioned explicitly. Someone was simply described as having been at a specific place. Examples of this are expressions like "at the time when she was at the farm," "for the short time... she spent there" or "he had been at the farm for half a year." 52 A full reading of such cases often shows that the people had worked at the place they were said to have been; talking about people's previous locations was an elliptical way of talking about their work. This interpretation can be questioned, but in view of how common it was to describe work in terms of the place where it was carried out, and/or the place where the master and/or mistress lived, I find it plausible.

50 Shepard, Accounting for Oneself, 174.

51 GaW Database, Uppsala University, 2020-03-17 14:43:08, case 10851 (original source: Riksarkivet, Svea Hovrätt, Advokatfiskalens arkiv EXIe, 2262).

52 GaW Database, Uppsala University, 2020-03-17 14:43:55, case 1401 (original source: Vadstenas landsarkiv, Göta hovrätt, EVAA, 48); GaW Database, Uppsala University, 2020-03-17 14:44:34, case 7949 (original source: Uppsalas landsarkiv, Örebro rådhusrätt och magistrat, A 1 A, 16); GaW Database, Uppsala University, 2020-03-17 14:45:21, case 381 (original source: Vadstenas landsarkiv, Göta hovrätt, EVAA, 40). 
In order to interpret the data correctly, we have to keep in mind that as much as $72 \%$ of all observations were made in court records (Table 4). Procedural rules about who could give evidence affected what sort of information the courts asked for and recorded. Thus, talking about where, when, for what duration, and for whom people worked was a way to place them geographically and socially. Eliciting or adding information of this kind helped courts establish the credibility of the persons in question and the possible biases in their accounts. Questions about responsibility and guilt also affected what was written down. In the case of a man described as working far away from his village (mentioned above), ${ }^{53}$ the court was investigating a fire that had broken out at a farm. Stressing that this man had worked far away from the farm that particular day was a way of exonerating him.

The cases focused on income sometimes came from accounts or from sources produced within the tax administration, but income could also be a topic that surfaced in court cases. The courts' interest in whether or not a wage had been paid was often prompted by the taxation system. In early modern Sweden, heads of households were liable to pay a special tax for any servant to whom they paid wages. Naturally, people did not want to pay more tax than absolutely necessary. It is against this backdrop that we should read three cases where it was specifically pointed out that maid servants staying in particular houses did not work for a wage. The tax implications of wage payments suggest that people had an interest in hiding paid work and that, in general, sources are likely to underreport paid work. Whether or not someone had been paid a wage is an issue likely to have taken up more of the court's time than had there not been any such tax implications.

The cases focused on contractual terms should be read against the backdrop of early modern labour legislation. As in many other European countries, young people in Sweden who lacked independent means were legally obliged to offer themselves for work. ${ }^{54}$ These laws provided

53 GaW Database, Uppsala University, 2020-03-17 14:47:32, case 10551 (original source: Riksarkivet, Svea Hovrätt, Advokatfiskalens arkiv EXIe, 2262)

54 Jane Whittle, "Introduction: Servants in the Economy and Society of Rural Europe," in Servants in Rural Europe 1400-1900, ed. Jane Whittle (Woodbridge: Boydell Press, 
heads of households with the instruments to force young people into service and to help them prosecute young people who left their service before the end of the agreed-upon time. ${ }^{55}$ The existence of this legislation accounts for the fact that "contract" was a common type of contextual information.

Thus, the patterns shown in Table 2 cannot be read naïvely as simple reflections of what people associated with their work. They reflect both the social and legal situations in which early modern people found themselves and the ways in which the sources filtered information. Different types of historical sources generate different types of descriptions.

\section{Vaguely described work by people in leading positions}

Delegation of work was probably widespread in early modern society. People transferred tasks and responsibilities to other people, sometimes within a commercialized framework and sometimes within a household context. In the former case, such practices can appear in the sources under the name of commissioning, a term that means approximately the same as the modern term sub-contracting. In the latter case, delegating responsibility and giving orders indicate hierarchical relations. In both cases, it is unlikely that the person who commissioned, ordered, or delegated work occupied a subordinate position in the household or in society. One member of the Gender and Work Project, Karin Hassan Jansson, has shown how both male and female heads of households "ordered," "governed," "assigned," and "asked" subordinate household members to do various things. Her analysis of these chains of command highlights that married women did managerial work and exercised authority more

2017): 1-18; Charmian Mansell, "Female Service and the Village Community in SouthWest England 1550-1650: The Labour Laws Reconsidered," in Servants in Rural Europe 1400-1900, ed. Jane Whittle (Woodbridge: The Boydell Press, 2017): 77-94, esp. 92-3; Jonas Lindström, Karin Hassan Jansson, Rosemarie Fiebranz, Benny Jacobsson, and Maria Ågren, "Mistress or Maid: The Structure of Women's Work in Sweden, 1550-1800," Continuity and Change 32 (2017): 225-52. 
often than has generally been assumed. The analysis also sheds new light on what tasks those in subordinate positions could do as representatives of their masters and mistresses. ${ }^{56}$

It would be useful, therefore, to find more indicators of delegating practices as these might help us find new examples of labour relations in the historical documents. Is it possible also to discern such practices behind vaguely described work? In Swedish early modern texts, a candidate is the verb låta, which often translates to "have" in English. In expressions such as (in translation) "have someone repair a boat," "have someone open a blood vessel," "have someone mend and alter [clothing]," "have the boys bring drinks," "have someone bandage a wound," "have Lars play the violin for us," and "have someone bury," låta consistently describes the transfer of a task or a responsibility to someone else, although in vaguer and subtler ways than the term order. Table 5 gives an overview of the meanings ascribed to låta in 101 cases of observed work, registered in the GaW database.

Table 5. Verb phrases including låta and describing work

\begin{tabular}{|l|l|l|}
\hline Meanings & Number of observations & Examples \\
\hline $\begin{array}{l}\text { = have someone do } \\
\text { gomething concrete, } \\
\text { give someone a task }\end{array}$ & $\begin{array}{l}\text { Male 30 } \\
\text { Female 5 }\end{array}$ & $\begin{array}{l}\text { have someone cut out a } \\
\text { pair of trousers (1401) } \\
\text { have someone construct } \\
\text { stairs (8996) }\end{array}$ \\
\hline $\begin{array}{l}\text { = confer responsibility } \\
\text { for something upon } \\
\text { someone, see to it that } \\
\text { something gets done }\end{array}$ & $\begin{array}{l}\text { Male 18 } \\
\text { Female 2 } \\
\text { = allow or accept } \\
\text { something someone bury } \\
\text { someone (6083) }\end{array}$ \\
\hline = let be, postpone & $\begin{array}{l}\text { Male 8 } \\
\text { Female 7 } \\
\text { Female 0 }\end{array}$ & $\begin{array}{l}\text { allow servant to do } \\
\text { something (2281) } \\
\text { accept being taught } \\
\text { something (3004) }\end{array}$ \\
\hline
\end{tabular}

56 Karin Hassan Jansson, Rosemarie Fiebranz, and Ann-Catrin Östman, "Constitutive Tasks: Performances of Hierarchy and Identity," in Making a Living, Making a Difference: Gender and Work in Early Modern European Society, ed. Maria Ågren (Oxford, New York: Oxford University Press, 2017): 127-58, esp. 140-6. 


\begin{tabular}{|l|l|l|}
\hline = make arrangement & $\begin{array}{l}\text { Male 0 } \\
\text { Female 1 }\end{array}$ & $\begin{array}{l}\text { arrange for something to } \\
\text { take place (11157) }\end{array}$ \\
\hline = sell, transfer right & $\begin{array}{l}\text { Male 3 } \\
\text { Female 0 }\end{array}$ & $\begin{array}{l}\text { transfer right to run inn } \\
(18677)\end{array}$ \\
\hline $\begin{array}{l}\text { = cede something to } \\
\text { someone }\end{array}$ & $\begin{array}{l}\text { Male 2 } \\
\text { Female 0 }\end{array}$ & $\begin{array}{l}\text { cede the right [to sell } \\
\text { liquor] to someone } \\
(2701)\end{array}$ \\
\hline = lock/unlock & $\begin{array}{l}\text { Male 2 } \\
\text { Female 0 }\end{array}$ & unlock the door (7806) \\
\hline remind & $\begin{array}{l}\text { Male 3 } \\
\text { Female 0 }\end{array}$ & $\begin{array}{l}\text { explain how they can } \\
\text { help (12780) }\end{array}$ \\
\hline Irrelevant & $\begin{array}{l}\text { Male 14 } \\
\text { Female 3 }\end{array}$ & $\begin{array}{l}\text { plåtar (= metal } \\
\text { currency) }\end{array}$ \\
\hline TOTAL & $\begin{array}{l}\text { Male 83 } \\
\text { Female 18 } \\
\text { Total 101 }\end{array}$ & \\
\hline
\end{tabular}

Comments: Search criteria: (Godkända fall): "Kön" = 'Man' AND "Verbfras (källa)" = '“låta*'; (Godkända fall): "Kön” = 'Kvinna' AND "Verbfras (källa)" = "“låta”'. GaW database, Uppsala University, 20200908, 15:43. Numbers in the column "Examples" refer to case numbers in the GaW database.

Table 5 shows that låta can be a deceptive indicator of delegation as it yields many false positives. First, some of the hits are irrelevant as they have nothing at all to do with work: illa låta means to make unpleasant sounds, plåtar means metal currency (and is caught in the net because the four letters in låta are part of plåtar), and Låta turns up as a misspelling of the name Lotta.

When these irrelevant examples have been sorted out, hits still remain that are less useful if our aim is to mine the sources for examples of work by people in leading positions. Meaning also "allow" and "accept", the verb låta frequently turns up in court records because courts allowed people to show their evidence and present their arguments, let things be (låta bero, låta saken anstå), and asked that people be left in peace (låta vara $i$ fred). In petitions, låta was probably over-used for reasons of politeness or caution. In one case, for example, a woman complained 
that the authorities had removed her stall from the street. She (or the person who penned the petition) described this as the authorities having "let" someone remove the stall, thus avoiding direct accusations against the authorities. ${ }^{57}$ Other cases also show that låta was used in too many different situations to be an entirely reliable indicator of delegation. The verb was used in expressions such as "I will not let myself be satisfied with this" (kan inte låta mig nöja) and it could also mean "unlock" (for instance a door).

Still, Table 5 supports the hypothesis that often, låta does turn up in phrases that describe managerial and other forms of work carried out by people in leading positions. If we disregard the irrelevant cases, 65 per cent of those remaining belong to the two first categories: have someone do something concrete or confer responsibility for something to someone.

The probably widespread use of delegation is an important feature in the history of work. Delegation could be formal or informal, commercialized or not. Historians of work and labour are particularly interested in examples of men delegating tasks and responsibilities to women and of women delegating tasks and responsibilities to men. There are probably many cases of mistresses delegating tasks and responsibilities to servants, but there may also be some examples of the opposite. Being able to search large volumes of text with computer-aided techniques to find examples of such practices would be highly useful.

\section{Looking for linguistic markers of labour relations}

The analysis showed that contrary to the task-specific verb phrases that regularly include a direct object (mow grass, repair shoes, paint portrait, collect tax money, etc.), vague verbs such as work, serve, and help often come with an indirect object. The most common way to determine the verb in the cases of unspecified work was to detail for whom the work had been carried out: a head of household, an employer, a relative. Various adverbial modifiers linking the work activity to a place, a point in

57 GaW Database, Uppsala University, 2020-03-18 14:09:59, case 8951 (original source: Stockholms stadsarkiv, Handelskollegium, E VII, 1). 
time or a duration of time could also determine these verbs. It would be interesting, therefore, to use word collocations with vague work verbs, indirect objects, and adverbial modifiers as linguistic markers of labour relations in early modern texts. The second and third most common types of information determining these verbs had to do with income and with contractual terms, that is, the various benefits, conditions, and demands connected with work. In these cases, it was not possible to identify specific grammatical entities as markers. Instead, specific keywords or collocations of keywords such as wage, pay, paid, enter service, and leave service may function as markers. Overall, the hypothesis that these vague verbs described work by people in subordinate positions was confirmed, but there were some exceptions.

The analysis also showed that verb phrases including låta often described work activities by people in leading positions. The verb captured both precisely formulated orders and more general delegation of responsibility. It could also designate transactions that involved an exchange of money. Overall, the hypothesis that this verb described managerial work and other activities by people in leading positions was corroborated, but there were many false positives. To be a useful indicator, verb phrases including låta will need to be better specified.

Thus, historians can identify parts of a text in which people talk vaguely about their own and other people's work, but in words that suggest the sorts of labour relations involved. With the help of these linguistic markers, computer linguists may in turn be able to construct programmes that can automatically identify parts of texts that are still buried in the archives, metaphorically speaking, holding interesting information for historians. Historians may then be able to make their searches both speedier and more reliable. ${ }^{58}$ Some of the findings will probably be brief and fragmentary, but others will open up rich and detailed cases. As Jane Whittle has pointed out, labour relations changed

58 See, e.g., Eva Pettersson, Spelling Normalisation and Linguistic Analysis of Historical Text for Information Extraction (Uppsala: Uppsala University, 2016); Eva Pettersson, Jonas Lindström, Benny Jacobsson, and Rosemarie Fiebranz, "HistSearch - Implementation and Evaluation of a Web-Based Tool for Automatic Information Extraction from Historical Text", Proceedings of the 3rd HistoInformatics Workshop, Krakow, Poland, 11 July 2016. 
in the early modern period, sometimes quite dramatically, but these processes are as yet incompletely understood. ${ }^{59}$ With a better empirical basis, we may be able better to explain such changes.

\section{Conclusion}

The analysis of vague verbs such as work and serve yielded empirical results that confirm some things we already knew and corroborate the usefulness of some previous approaches. It is, for instance, striking how well Karin Hofmeester's general definition of labour relation fits with the data from early modern Sweden presented here: "with and for whom you work and under what rules." In more than 50 per cent of all cases in Table 2, work was described in terms of for whom, where, when, and for what duration it had taken place. Vaguely described work could also be defined in terms of income or as an (often implicit) contract; together, such descriptions made up 33 per cent of the data. These descriptions said something important about the rules under which work had taken place. In total, nearly 90 per cent of all contextual information describing work and serve dealt with "for whom" (including when, where and for how long) and "under what rules." The analysis of another vague verb, låta, suggested that while work and serve often reported subordinate positions, låta may serve to indicate (somewhat unreliably) work by people in leading positions. However, work activities by people in leading positions seem to fit less well with the definition of labour relations. It would be misleading to say that when a mistress deployed the labour of her servant, she worked with the servant. It would be more correct to say that she worked through the servant, or with the servant as her instrument.

The vague descriptions of work often highlighted the many relationships and dependencies that work could bring about. It was seldom possible to distinguish between external and internal characterizations, that is, between cases in which people described themselves and those

59 Whittle, "Introduction", 11, 18. 
in which they described others. Nevertheless, external characterizations probably had a strong impact on people's identities, and it is reasonable to think that many people had, in Mark Hailwood's words, "work-based" identities. The results strongly suggest that when people talked about for whom and under what rules they worked, they were in fact expressing work-based identities. ${ }^{60}$

The main purpose of this article is not, however, to arrive at new empirical results about the past, but to identify linguistic markers that might be useful in larger-scale analyses of past labour relations. The amount of unprinted archival documents that historians have not even started to look at provides an argument for why as a discipline we should engage with digital humanities and in cross-disciplinary projects. We need efficient ways of tracking down more new information, not least information on what labour relations in the past meant in practice rather than in theory. We tend to assume, for instance, that in early modern society young people in employment were always hired as long-term servants, because this is what early modern labour legislation prescribed. We also assume that this restricted young people's freedom in a number of ways. However, Charmian Mansell has found evidence of young people hired on much shorter-term contracts, giving them more freedom to negotiate their terms of payment. ${ }^{61}$ This finding illustrates that while it is true that early modern society was organized on principles of strict hierarchy and difference, ${ }^{62}$ it is also true that in order for this society to work, a certain flexibility was required in everyday life. We need to know more about the dynamics and limits of such flexibility. Kostas Vlassopoulos has argued that slavery in ancient Greece should be conceptualized as a dynamic relationship of domination, not as a property relation with a fixed meaning. The same is probably true of all work relationships. ${ }^{63}$

\footnotetext{
60 Hailwood, "Honest Tradesman," 82.

61 Charmian Mansell, "Female Service and the Village Community in South-West England 1550-1650: The Labour Laws Reconsidered," in Servants in Rural Europe 1400 1900, ed. Jane Whittle (Woodbridge: The Boydell Press, 2017): 77-94, esp. 92-93. Margaret R. Hunt, Women in Eighteenth-Century Europe (Harlow: Pearson Education, 2010), 13-48.

63 Vlassopoulos, "Greek Slavery."
} 


\section{Bibliography}

\section{Primary sources:}

All primary sources are from the Gender and Work (GaW) database, where they can be accessed by everyone: https://gaw.hist.uu.se/

\section{Secondary sources:}

Ågren, Maria. "Conclusion." In Making a Living, Making a Difference: Gender and Work in Early Modern European Society, edited by Maria Ågren, 204-20. Oxford, New York: Oxford University Press, 2017.

Ågren, Maria. "Emissaries, Allies, Accomplices and Enemies: Married Women's Work in Eighteenth-century Sweden." Urban History 41 (2014): 394-414. Ågren, Maria. "Introduction: Making a Living, Making a Difference." In Making a Living, Making a Difference: Gender and Work in Early Modern European Society, edited by Maria Ågren, 1-23. Oxford, New York: Oxford University Press, 2017.

Ågren, Maria. The State as Master. Gender, State Formation and Commercialisation in Urban Sweden, 1650-1780. Manchester: Manchester University Press, 2017.

Ågren, Maria, ed. Making a Living, Making a Difference: Gender and Work In Early Modern European Society. Oxford, New York: Oxford University Press, 2017. Allen, Robert. "The High Wage Economy and the Industrial Revolution: A Restatement." Economic History Review 68, no. 1 (2015): 1-22.

de Vries, Jan. "The Industrial Revolution or the Industrious Revolution." Journal of Economic History 54 (1994): 249-70.

Esquivel, Valeria, Debbie Budlender, Nancy Folbre, and Indira Hirway. "Explorations: Time-use Surveys in the South." Feminist Economics 14 (2008): 107-52.

Gary, Kathryn E. Work, Wages and Income. Remuneration and Labor Patterns in Sweden 1500-1850. Lund: Lund University, 2018.

Guldi, Jo and David Armitage. The History Manifesto. Cambridge: Cambridge University Press, 2014.

Hacking, Ian. “Making Up People." In Ian Hacking, Historical Ontology, 99-114. Cambridge MA, London: Harvard University Press, 2002. 
Hailwood, Mark. “'The Honest Tradesman's Honour': Occupational and Social Identity in Seventeenth-century England." Transactions of the Royal Historical Society 24 (2014): 79-103.

Hofmeester, Karin, Jan Lucassen, Leo Lucassen, Rombert Stapel, and Richard Zijdeman. "The Global Collaboratory on the History of Labour Relations, 1500-2000: Background, Set-Up, Taxonomy, and Application." International Institute of Social History 26 October 2015, https://collab.iisg.nl/ web/labourrelations (downloaded 20200904, 10:37).

Humphries, Jane and Benjamin Schneider. "Spinning the Industrial Revolution." Economic History Review 72, no. 1 (2019): 126-55.

Humphries, Jane and Jacob Weisdorf. "The Wages of Women in England, 12601850." Journal of Economic History 75 (2015): 405-47.

Hunt, Margaret R. Women in Eighteenth-Century Europe. Harlow: Pearson Education, 2010.

Jansson, Karin Hassan. "Pigors arbete och vardag i det tidigmoderna Sverige [Maids' work and everyday life in early modern Sweden]." Personhistorisk Tidskrift 109 (2013): 137-58.

Jansson, Karin Hassan, Rosemarie Fiebranz, and Ann-Catrin Östman. "Constitutive Tasks: Performances of Hierarchy and Identity." In Making a Living, Making a Difference: Gender and Work In Early Modern European Society, edited by Maria Ågren, 127-58. Oxford, New York: Oxford University Press, 2017. Keibeck, Sebastian A. J. and Leigh Shaw-Taylor. "Early Modern Rural ByEmployments: A Re-Examination of the Probate Inventory Evidence." Agricultural History Review 61 (2013): 244-81.

Lennersand, Marie, Jan Mispelaere, Christopher Pihl, and Maria Ågren. "Gender, Work, and the Fiscal-Military State." In Making a Living, Making a Difference: Gender and Work in Early Modern European Society, edited by Maria Ågren, 178-203. Oxford, New York: Oxford University Press, 2017.

Lindström, Jonas, Rosemarie Fiebranz, and Göran Rydén. "The Diversity of Work." In Making a Living, Making a Difference: Gender and Work in Early Modern European Society, edited by Maria Ågren, 24-56. Oxford, New York: Oxford University Press, 2017.

Lindström, Jonas, Karin Hassan Jansson, Rosemarie Fiebranz, Benny Jacobsson, and Maria Ågren. "Mistress or Maid: The Structure of Women's Work in Sweden, 1550-1800." Continuity and Change 32 (2017): 225-52. 
Mansell, Charmian. "Female Service and the Village Community in South-West England 1550-1650: The Labour Laws Reconsidered." In Servants in Rural Europe 1400-1900, edited by Jane Whittle, 77-94. Woodbridge: Boydell Press, 2017.

McIntyre, Lee. The Scientific Attitude. Defending Science from Denial, Fraud, and Pseudoscience Cambridge, London: MIT Press, 2019.

Ogilvie, Sheilagh. A Bitter Living. Women, Markets, and Social Capital in Early Modern Germany. Oxford, New York: Oxford University Press, 2003.

Østhus, Hanne. "Contested Authority: Master and Servant in Copenhagen and Christiania, 1750-1850." Unpublished Ph.D. thesis, European University Institute, Florence, 2013.

Østhus, Hanne. "Servants in Rural Norway, ca. 1650-1800." In Servants in Rural Europe 1400-1900, edited by Jane Whittle, 113-130. Woodbridge: Boydell Press, 2017.

Östman, Ann-Catrin. Mjölk och jord. Om kvinnlighet, manlighet och arbete i ett österbottniskt jordbrukarsamhälle ca 1870-1940 [Milk and soil. On femininity, masculinity, and work in an Ostrobothnian farming society around 1870 1940]. Åbo: Åbo Akademis Förlag, 2000.

Overton, Mark, Jane Whittle, Darron Dean, and Andrew Hann. Production and Consumption in English Households, 1600-1750. London, New York: Routledge, 2004.

Pettersson, Eva. Spelling Normalisation and Linguistic Analysis of Historical Text for Information Extraction. Doctoral thesis, Department of Linguistics and Philology, Uppsala University, 2016.

Pettersson, Eva, Jonas Lindström, Benny Jacobsson, and Rosemarie Fiebranz. "HistSearch - Implementation and Evaluation of a Web-based Tool for Automatic Information Extraction from Historical Text." Proceedings of the 3rd HistoInformatics Workshop, Krakow, Poland, 11 July 2016.

Shaw-Taylor, Leigh and E. A. Wrigley. "Occupational Structure and Population Change." In The Cambridge Economic History of Modern Britain. Vol. 1, Industrialisation, 1700-1870, edited by Roderick Floud, Jane Humphries, and Paul Johnson, 53-88. Cambridge: Cambridge University Press, 2014.

Shepard, Alexandra. Accounting for Oneself. Worth, Status, \& Social Order in Early Modern England. Oxford, New York: Oxford University Press, 2015. 
Terras, Melissa, Julianne Nyhan, and Edward Vanhoutte. Defining Digital Humanities: A Reader. Farnham: Ashgate, 2013.

Thomas, Keith. The Ends of Life. Roads to Fulfilment in Early Modern England. Oxford, New York: Oxford University Press, 2009.

Thompson, E.P. "Time, Work-Discipline, and Industrial Capitalism." Past and Present 38 (1967): 56-97.

Vlassopoulos, Kostas. "Greek Slavery: From Domination to Property and Back Again.” Journal of Hellenic Studies 131 (2011): 115-130.

Whittle, Jane. "Introduction: Servants in the Economy and Society of Rural Europe." In Servants in Rural Europe 1400-1900, edited by Jane Whittle, 1-18. Woodbridge: Boydell Press, 2017.

Whittle, Jane, ed. Servants in Rural Europe 1400-1900. Woodbridge: Boydell Press, 2017.

Whittle, Jane and Mark Hailwood. "The Gender Division of Labour in Early modern England." Economic History Review 73 (2020): 3-32. 

For further titles see: www.ebverlag.de

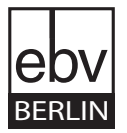

EBVERLAG DR. BRANDT

\section{WWW·EBVERLAG·DE}

Rainer Kuhl Tel.: 00493068977233

Jägerstraße 47 Fax:0049 3091607774

13595 Berlin E-Mail: post@ebverlag.de 
We can describe work in many ways: as income, prestigious titles, and concrete tasks. We can also describe work vaguely, simply as 'working', 'serving', 'helping' or 'being'. In the past as today, this was often true for work carried out by people in subordinate positions. However, the work of those in leading positions could also be talked about in unspecific and blank terms. While the vagueness of historical sources with respect to work can be annoying to the historian of labor, the good news is that sources can instead be more vocal about the social and economic relations that people were entangled in because of their work: with and for whom they worked and under what rules. This book uses evidence from early modern Sweden to discuss these patterns, showing that a common way of talking about one's work was to specify whom it benefitted: an employer, a family member, a relative. The author suggests ways in which historians and computer linguists can join forces efficiently to uncover the many dependencies that work has created over time.

\section{THE AUTHOR}

Maria Ågren is professor of history at Uppsala University, Sweden. Her work focuses on the intersection of economic, social, legal and gender history. Among her monographs are Domestic Secrets: Women and property in Sweden, 1600-1857 (University of North Carolina Press 2009) and The State as Master: Gender, state formation and commercialisation in urban Sweden, 1650-1780 (Manchester University Press 2017). She is the leader of the Gender and Work research project and the GaW infrastructure project; in this context, she has published a number of methodologically oriented articles and has also edited the project publication Making a Living, Making a Difference: gender and work in early modern European society (Oxford University Press 2017). 